УДК 616.34-002.253

М. В. Горіла, І. А. Кленіна, А. Ю. Широкова

Дніпропетровський національний університет ім. Олеся Гончара, НДІ гастроентерологї

\title{
ДОСЛІДЖЕННЯ БІОХІМІЧНИХ ПОКАЗНИКІВ ПРИ ХВОРОБАХ ШЛУНКОВО-КИШКОВОГО ТРАКТУ
}

Досліджено біохімічні показники сироватки крові людини: систему перекисного окиснення, загальний вміст ліпідів, холестеролу, ліпопротеїнів високої щільності, триацилгліцеролів та церулоплазміну за умов хронічних неспецифічних запальних захворювань кишок. Проаналізовано отримані дані з боку біохімічних показників та частоти відхилень показників у сироватці крові від норми у хворих на вищезазначені патології. Встановлено наявність біохімічних змін у хворих на запальні захворювання кишок з боку ліпідного обміну та системи перекисного окиснення, які відіграють головну роль у патогенетичних механізмах цих захворювань, мають свої клінічні прояви та потребують терапевтичної корекції.

\author{
M. V. Gorelaya, I. A. Klenina, A. U. Shirokova \\ Oles' Gonchar Dnipropetrovsk National University, \\ Research Institute of Gastroenterology

\section{INVESTIGATION OF BIOCHEMICAL INDICES UNDER GASTRIC DESORDERS}

The peroxidation system, general lipids, cholesterol, triglycerides, ceruloplasmin contents were examined under chronic non-specific inflammatory intestine diseases. The biochemical indices and deflexion frequency of pathological serum were analised. The biochemical changes were established in the blood serum of patients under chronic non-specific inflammatory intestine diseases. These changes play the most important role in the pathogenetic mechanisms, have their own clinical manifestations and demand the therapeutical correction.

\section{Вступ}

Хронічні неспецифічні запальні захворювання кишок (ХНЗК) - неспецифічний виразковий коліт (НВК) і хвороба Крона (ХК) - важкі захворювання з невідомою етіологією, поширеність яких у всьому світі зростає $[1 ; 8]$. Дані хвороби стали поширюватися серед дедалі молодших людей $[11 ; 12 ; 13]$. Через відсутність чітких уявлень про етіологію та патогенез ХНЗК лікування їх розроблено недостатньо, часто воно малоефективне. Це призводить до розвитку небезпечних для життя ускладнень, формування резистентних форм захворювань, втрати працездатності та виходу на інвалідність осіб молодого віку [14].

Аналіз накопиченого різними вченими досвіду свідчить про те, що на сьогодні ні бактеріальна або вірусна агресія зі стійкими порушеннями біоценозу кишечника, ні порушення нейровегетативновісцеральних або психосоматичних взаємозв'язків, ні генетична схильність до хвороби імунної системи, ні інші, окремо взяті концепції, не

() М. В. Горіла, І. А. Кленіна, А. Ю. Широкова, 2009 
роз'яснюють поодинці усього різноманіття клінічних симптомів НВК та ХК, а тому і не можуть у повній мірі претендувати на головне положення, яке роз'яснює виникнення захворювання у конкретного пацієнта [13].

Одним із важливих механізмів розвитку неспецифічних запальних захворювань кишок, за сучасними уявленнями, $є$ вільнорадикальні окисні процеси та порушення ліпідного обміну. Вивчення продуктів системи перекисного окиснення ліпідів (ПОЛ) та ліпідних показників у хворих на ХНЗК досить актуальне та перспективне, воно дасть можливість позитивного лікувального впливу на перебіг даної патології [3; 4; 7]. Також детальний аналіз роботи систем ПОЛ-АОЗ при даних патологіях дасть можливість якісного контролю за процесами терапії у динаміці $[9 ; 15 ; 18 ; 19]$.

Мета роботи - виявити біохімічні особливості ураження шлунково-кишкового тракту у хворих на хворобу Крона та неспецифічний виразковий коліт. Завдання дослідження - вивчити особливості змін біохімічних показників крові у хворих на НВК та ХК, дослідити у цих хворих ліпідний обмін та стан системи ПОЛ.

\section{Матеріал і методи досліджень}

За об’єкти вивчення взяті зразки сироватки крові хворих на хронічні неспецифічні захворювання кишок. Залежно від патології захворювання хворі розподілені на дві групи: I група - 7 пацієнтів на ХК віком $47,1 \pm 5,9$ року, II група - 7 пацієнтів на НВК віком $45,7 \pm 3,2$ року. Стан системи ПОЛ оцінювали за концентрацією малонового діальдегіду (МДА) у плазмі. Для характеристики ліпідного обміну визначали вміст загальних ліпідів, холестеролу, ліпопротеїнів високої щільності (ЛПВЩ), триацилгліцеринів. Порівняльний аналіз проведений із показниками у III контрольній групі, яку склали 20 практично здорових осіб.

Оцінку показників давали відповідно до їх змін: МДА у плазмі - 1,902,16 нмоль/мл, ЛПВЩ - 0,8-2,2 ммоль/л, церулоплазміну - 300,0-380,0 мг/л, загальних ліпідів - 4,0-8,0 г/л, триацилгліцерину - 0,45-1,86 ммоль/л, холестеролу - 3,646,76 ммоль/л.

Стан ПОЛ оцінювали за концентрацією малонового діальдегіду у плазмі крові, визначили активність ферменту церулоплазміну. МДА визначали за інтенсивністю забарвлення триметилового комплексу, який утворюється в кислому середовищі при реагуванні МДА з 2-тіобарбітуровою кислотою. Активність церулоплазміну визначали за модифікованим методом Ревіна, принцип якого базується на окисненні $p$-фенілендіаміну за участі церулоплазміну. Порушення ліпідного обміну визначали за концентрацією холестеролу, тригліцеридів, ЛПВЩ $[11 ; 16]$.

Холестерол визначали методом Ілька. Принцип методу базується на забарвленні холесторолу у зелений колір у присутності сірчаної та оцтової кислот. Тригліцериди визначали при омиленні їх гідроксидом калію в гліцерин, при окисненні якого виникає формальдегід. Формальдегід визначали за реакцією з метилен-ацетоном і амонієвими іонами як жовтий 3,5-діацеїл-1,4-дигідролутидин. ЛПВЩ визначали після осадження $\beta$-ліпопротеїдів гепарином у присутності солей марганцю. Загальні ліпіди визначали методом, який базується на взаємодії ліпідів після гідролізу сірчаної кислоти з фосфованіловим реактивом з утворенням червоного забарвлення [11;17].

Для статистичного аналізу даних використовували дескриптивну статистику; порівняння середніх значень змінних здійснювали за допомогою параметричних методів ( $t$-критерію Стьюдента) за нормального розподілу даних ознак, що виражені в інтервальній шкалі. Всі розрахунки виконували у програмі SPSS 9.0 for Windows. 
Всі засоби вимірювальної техніки, які використовувались під час виконання роботи, пройшли метрологічну повірку в установленому порядку.

\section{Результати та їх обговорення}

Отримані дані дозволили охарактеризувати біохімічні показники сироватки крові у хворих на ХК та НВК. На сьогодні накопичено численні експериментальні та клінічні дані, які свідчать про те, що тривала активація процесів вільнорадикального окиснення за умов поступового виснаження резервів антиоксидантного захисту організму супроводжується посиленням деструктивних процесів і збільшенням важкості перебігу захворювань. При цьому складність ранньої діагностики захворювань пов'язана 3 невирішеністю проблеми визначення критеріїв розмежування фізіологічних і патологічних змін, що спостерігаються при окисному стресі [4]. Останнім часом продовжує збільшуватися кількість повідомлень, які стосуються систем перекисної оксидації ліпідів (ПОЛ) та антиоксидантного захисту (АОЗ) при захворюваннях внутрішніх органів $[2 ; 5 ; 10 ; 14]$.

У хворих на ХК підвищується вміст МДА, ЦП (табл. 1) та порушуються показники ліпідного обміну (холестерол, загальні ліпіди).

Біохімічні показники сироватки крові $(M \pm m)$ обстежених хворих

Таблиия 1 на хворобу Крона та неспецифічний виразковий коліт

\begin{tabular}{|l|c|c|c|}
\hline \multicolumn{1}{|c|}{ Біохімічний показник } & Контрольний показник, $n=20$ & $\mathrm{XK,} n=7$ & $\mathrm{HBK,} n=7$ \\
\hline Холестерол, ммоль/л & $5,20 \pm 0,60$ & $4,83 \pm 0,52$ & $5,73 \pm 0,43$ \\
\hline МДАпл, нмоль/мл & $2,03 \pm 0,13$ & $2,82 \pm 0,24^{* *}$ & $3,25 \pm 0,47^{*}$ \\
\hline ЦП, мг/л & $308,0 \pm 8,8$ & $399,4 \pm 28,3^{*}$ & $371,9 \pm 34,9$ \\
\hline Загальні ліпіди, г/л & $6,00 \pm 0,70$ & $4,56 \pm 0,51$ & $4,02 \pm 0,30^{*}$ \\
\hline Триацилгліцериди, ммоль/л & $0,92 \pm 0,12$ & $0,98 \pm 0,12$ & $0,95 \pm 0,10$ \\
\hline ЛПВЩ, ммоль/л & $1,40 \pm 0,11$ & $1,39 \pm 0,21$ & $1,27 \pm 0,16$ \\
\hline
\end{tabular}

Примітки: * $-p<0,05, * *-p<0,01$ вірогідність розбіжності між показниками хворих порівняно 3 групою контролю.

У цьому випадку вірогідні зміни біохімічних показників у хворих на ХК стосувалися підвищеного вмісту МДА, церулоплазміну та порушення показників ліпідного обміну (холестерол, загальні ліпіди). На наступному етапі роботи провели аналіз частоти виявлення відхилень біохімічних показників сироватки крові від норми у хворих на ХК (табл. 2).

Табличя 2

Частота виявлення відхилень біохімічних показників сироватки крові від норми у хворих на хворобу Крона

\begin{tabular}{|l|c|c|c|c|c|c|}
\hline \multirow{2}{*}{ Показник } & \multicolumn{2}{c|}{ Норма } & \multicolumn{2}{c|}{ Підвиення } & \multicolumn{2}{c|}{ Зниження } \\
\cline { 2 - 7 } & $\%$ & $M \pm m$ & $\%$ & $M \pm m$ & $\%$ & $M \pm m$ \\
\hline Холестерол, ммоль/л & 85,7 & $5,24 \pm 0,37$ & - & - & 14,3 & 2,34 \\
\hline МДАпл, нмоль/мл & 28,6 & $2,06 \pm 0,09$ & 71,4 & $3,12 \pm 0,20$ & - & - \\
\hline Церулоплазмін, мг/л & 28,6 & $363,1 \pm 13,1$ & 57,1 & $448,4 \pm 21,8$ & 14,3 & 275,6 \\
\hline Загальні ліпіди, г/л & 71,4 & $4,96 \pm 0,62$ & - & - & 28,6 & 3,58 \\
\hline Триацилгліцериди, ммоль/л & 85,7 & $1,08 \pm 0,08$ & - & - & 14,3 & 0,41 \\
\hline ЛПВЩ, ммоль/л & 100,0 & $1,39 \pm 0,21$ & - & - & - & - \\
\hline
\end{tabular}

Примітка: відмінності не зареєстровані.

Під час аналізу активності АO3, яка є ключовим механізмом захисту організму від надлишкового утворення продуктів ПОЛ, установлені такі зміни вмісту клітинного ферменту церулоплазміну: у 57,1 \% хворих на ХК він підвищувався до 448,4 мг/л 
( $p<0,05)$, оскільки ЦП відносять до гострофазних білків, його концентрація може підвищуватися при запальних захворюваннях, які супроводжуються гострофазною відповіддю; у 14,3 \% хворих на ХК переважала недостатність цього фактора антиоксидантного захисту, що може відбуватися в результаті як порушеного всмоктування в кишечнику, так і зниження синтезу при супутніх захворюваннях гепатобіліарної системи.

Характерне підвищення рівня МДА у плазмі крові у 71,4 \% хворих у 1,3 раза. Вміст холестеролу у більшості хворих $(85,7$ \%) не відрізнявся від нормальних показників і лише у одного хворого зменшувався в 2,3 раза. Ліпопротеїни високої щільності (ЛПВЩ, $\alpha$-ХС) перебували практично у межах норми 1,39 ммоль/л. Вміст загальних ліпідів у переважної кількості пацієнтів $(71,4$ \%) не був змінений, у 28,6 \% хворих знижувався в 1,7 раза. Вміст триацилгліцеридів не відрізнявся від норми у 85,7 \% хворих, у решти - був зменшений у 2,2 раза і становив 0,41 моль/л, що може бути наслідком порушення перетравлення нейтральних жирів їжі та всмоктування продуктів їі розщеплення у тонкій кишці.

Охарактеризували також інший параметр - частоту виявлення відхилень біохімічних показників сироватки крові від норми у хворих на НВК (табл. 3).

Таблиия 3

Частота виявлення відхилень біохімічних показників сироватки крові від норми у хворих на неспецифічний виразковий коліт

\begin{tabular}{|l|c|c|c|c|c|c|}
\hline \multirow{2}{*}{ Показник } & \multicolumn{2}{c|}{ Норма } & \multicolumn{2}{c|}{ Підвищення } & \multicolumn{2}{c|}{ Зниження } \\
\cline { 2 - 7 } & $\%$ & $M \pm m$ & $\%$ & $M \pm m$ & $\%$ & $M \pm m$ \\
\hline Холестерол, ммоль/л & 71,40 & $5,17 \pm 0,34$ & 28,60 & $7,12 \pm 0,23$ & - & - \\
\hline МДАпл, нмоль/мл & - & - & 71,40 & $3,80 \pm 0,45$ & 28,60 & 1,88 \\
\hline ЦП, мг/л & 42,90 & $326,7 \pm 20,6$ & 42,90 & $460,8 \pm 15,4$ & 14,20 & 240,6 \\
\hline Загальні ліпіди, г/л & 42,90 & $4,76 \pm 0,29$ & - & - & 57,10 & $3,46 \pm 0,18$ \\
\hline Триацилгліцериди, ммоль/л & 100,00 & $0,95 \pm 0,10$ & - & - & - & - \\
\hline ЛПВЩ, ммоль/л & 85,70 & $1,37 \pm 0,37$ & - & - & 14,30 & 0,68 \\
\hline
\end{tabular}

Примітка: відмінності не зареєстровані.

Зміна активності церулоплазміну у хворих на НВК мала різноспрямований характер, що проявлялося як підвищенням його у 42,9 \% пацієнтів у 1,5 раза, так і зниженням у одного хворого в 1,3 раза; останнє може бути характерним для хронізації процесу запалення $[2 ; 15]$. Церулоплазмін - головний фермент плазми, який бере участь у процесі антиоксидантного захисту. Підвищення його активності трактується деякими дослідниками як проявлення “гострофазної” відповіді, участь у якій залежить від стану інтерлейкіну. Тому підвищену його активність у 42,9 \% обстежених хворих на НВК та ХК можна розцінювати як прояв компенсаторної реакції в системі антиоксидантного захисту. Зниження вмісту церулоплазміну у плазмі крові характерне для хронізації процесу запалення. Зміна рівня МДА у плазмі хворих на НВК мала різноспрямований характер: рівень МДА був підвищений у 71,4 \% хворих у 1,9 раза, у 28,6 \% хворих - зменшений у 1,1 раза. Вміст холестеролу у більшості хворих на НВК $(71,4 \%)$ не відрізнявся від нормальних показників і лише в 28,6 \% спостережень збільшувався в 1,4 раза. Вміст ліпідів у переважної кількості пацієнтів $(57,1$ \%) був зменшений у 1,7 раза, у 42,9 \% залишався у межах норми. Вміст тригліцеридів не відрізнявся від норми.

Характер змін вмісту ліпопротеїнів високої щільності (основної транспортної форми холестеролу) знизився у 14,3 \% хворих у 2,1 раза, що свідчило про порушення обміну та транспорту холестеролу. Таким чином, для хворих на ХК та НВК більш характерними змінами виявилися порушення ліпідного обміну. Як видно з порівняння 
результатів досліджень у хворих на хворобу Крона та неспецифічний виразковий коліт, останній має вищу активність запального процесу.

\section{Висновки}

Для групи хворих на ХНЗК виявлене порушення обміну загальних ліпідів, показники яких зменшувались у 28,6 \% хворих на ХК і у 57,1 \% хворих на НВК, та порушення синтезу і транспорту холестеролу у $28,6 \%$ хворих на НВК $(p<0,05)$, що може бути наслідком порушення перетравлення нейтральних жирів їжі та всмоктування продуктів ії розщеплення у тонкій кишці. У хворих на ХК рівень холестеролу не відрізнявся від нормальних показників.

У групі хворих на ХК та НВК на фоні зниження антиоксидантного захисту характерне посилення процесів ліпопероксидації, що проявлялося підвищенням вторинного продукту ПОЛ - МДА у плазмі 71,4 \% хворих на НВК та ХК $(p<0,01)$. У 28,6 \% хворих на НВК виявлено виснаження оксидантного статусу у вигляді зниження рівня МДА $(p<0,01)$, що може означати виснаження оксидантної системи. Виявлено підвищення вмісту церулоплазміну у $42,9 \%$ хворих на НВК та у $57,1 \%$ на ХК $(p<0,05)$, що характерно для хронізації процесу запалення.

Проведені дослідження дозволили встановити наявність біохімічних змін у хворих на запальні захворювання кишок з боку ліпідного обміну та системи ПОЛ-АОЗ, які відіграють головну роль у патогенетичних механізмах цих захворювань, мають свої клінічні прояви та потребують терапевтичної корекції.

\section{Бібліографічні посилання}

1. Балтайтис Ю. В. Неспецифический язвенный колит / Ю. В. Балтайтис, В. Е. Кушнир, А. И. Корсунский. - К. : Здоров'я, 1986. - 192 с.

2. Береза Н. М. Ефективність імуностимуляції гамаглобуліном при неспецифічному виразковому коліті // Гастроентерологія. - Д. : НДІ гастроентерології, 2003. - Вип. 34. - С. 453-458.

3. Бєленічев І. Ф. Антиоксиданти: сучасне уявлення, перспективи створення / І. Ф. Бєленічев, С. І. Коваленко, В. В. Дунаєв // Ліки. - 2002. - № 1. - С. 25-29.

4. Владимиров Ю. А. Перекисное окисление липидов в биологических мембранах / Ю. А. Владимиров, А. И. Арчаков. - М. : Наука, 1972. -252 с.

5. Вороб̆ьев Г. И. Клинико-морфологическая характеристика сегментарного поражения при язвенном колите / Г. И. Воробьев, И. Л. Халиф, Н. С. Малахова // Клиническая медицина. 2007. - № 1. - С. $44-47$.

6. Гриднєв О. С. Перекисне окиснення ліпідів і печінка // Сучасна гастроентерологія. - 2005. № 5. - C. 80-83.

7. Гриненко Е. В. Перекисное окисление липидов у больных язвенной болезнью двенадцатиперстной кишки с нерубцующимися язвенными дефектами // Новое в профилактике, диагностике и лечении основных заболеваний внутренних органов. - Харьков : ХМУ, 1994. - С. 42-44.

8. Дегтярева И. И. Язвенная болезнь // Заболевания органов пищеварения. - К. : Медицина, 2000. - C.41-44.

9. Журавлев Л. И. Биоантиокислители в животном организме // Биоантиокислители. - М. : Наука, 1975. - $158 \mathrm{c}$.

10. Звягинцева Т. Д. Патогенетичні механізми ліпопероксидації та антирадикального захисту в розвитку виразкової хвороби дванадцятипалої кишки / Т. Д. Звягинцева, А. И. Чернобай, М. Д. Дахер // Сучасна гастроентерологія. - 2002. - № 1. - С. 49-52.

11. Камышников В. С. Справочник по клинико-биохимической лабораторной диагностике. В 2 т. 2-е изд. - Мн. : Беларусь, 2002. -280 с.

12. Коган А. Х. Активные формы кислорода, лейкоциты и патогенез гастродуоденальной язвенной болезни / А. Х. Коган, А. П. Погромов. - М. : ММА им. И. М. Сеченова, 1991. - 270 с. 
13. Копейкин В. Н. Механизмы формирования неспецифического язвенного колита у детей / В. Н. Копейкин, Л. И. Лозовская // Педиатрия. - 1997. - № 1. - С. 30-32.

14. Особливості перекисного окислення ліпідів у пацієнтів із хронічними неспецифічними запальними захворюваннями кишок та супутньою патологією гепатобіліарної системи / Н. М. Береза, Т. Й. Бойко, О. В. Лелюхіна та ін. // Гастроентерологія. - Д. : НДІ гастроентерології, 2003. - Вип. 34. - С. 217-223.

15. Спектор Е. Б. Определение общей антиокислительной активности плазмы крови и ликвора / Е. Б.Спектор, А. А. Анапенко, Л. Н. Политова // Лабораторное дело. - 1984. - № 1. - С. 26-28.

16. Шевченко О. П. Клініко-діагностичне значення церулоплазміну / О. П. Шевченко, О. В. Орлова // Клініч. лаб. діагностика. - 2006. - № 7. - С. 23-33.

17. Шеленкова Л. Н. Структура, биосинтез и превращение липидов в организме животного и человека / Л. Н. Шеленкова., М. В. Биленко. - Л. : ЛГУ, 1978. - 320 с.

18. Эседов Э. М. Характеристика перекисного окисления липидов и антиоксидантной активности слизистой оболочки двенадцатиперстной кишки у больных язвенной болезнью / Э. М. Эседов, С. Н. Мамаев // Терапевтич. архив. - 1998. - № 2. - С. 32-35.

19. Яковлева Л. В. Перекисне окиснення ліпідів та антиоксиданти при виразковій хворобі шлунка / Л. В. Яковлева, Т. С. Сахарова, Л. Д. Бунтян // Клін. фармація. - 1999. - Т. 3, № 1. - С. 27-29.

Надійшла до редколегї 11.02.2009 